\title{
Epicardial adipose tissue is a predictor of ascending aortic dilatation in hypertensive patients, but not paracardial adipose tissue
}

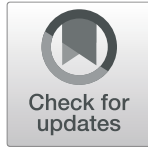

\author{
Onur Argan*, Eyup Avci, Tarik Yildirim and Ozgen Safak
}

\begin{abstract}
Background: Ascending aortic aneurysms are one of the major causes of mortality. In recent years, there is a growing interest of epicardial adipose tissue (EAT) and related diseases. The aim of this study was to investigate the relationship of EAT, and PAT with ascending aortic dilatation (AAD).

Methods: We included 934 patients with hypertension in this study. The patients were evaluated by a complete transthoracic echocardiographic examination, including measurements of EAT, PAT, and aortic dimensions. Aortic size index (ASI) was used for diagnosing AAD. The patients were divided into two groups: dilated ascending aorta diameter (ASI $\geq 21 \mathrm{~mm} / \mathrm{m}^{2}, n=102$ ) or normal aortic diameter (ASI $<21 \mathrm{~mm} / \mathrm{m} 2, n=832$ ) according to the ASI. Characteristics of these patients were compared before and after propensity score matching analysis.

Results: Patients with AAD were older (72.3 \pm 11.6 vs. $61.7 \pm 12.7$ years, $p<0.001)$, had more female gender (66\% vs. $54 \%, p=0.021$ ) than patients with normal ascending aorta (AA). After propensity score matching analysis (77 vs. 77), EAT [OR:1.461, \%95Cl (1.082-1.974), $p=0.013$ ] was independently associated with AAD in multivariate logistic regression analysis. In ROC curve analysis, EAT $>0.45 \mathrm{~cm}$ had $51.9 \%$ sensitivity and $62.3 \%$ specificity [AUC $=0.617$, $P=0.012,95 \% \mathrm{Cl}(0.529-0.707)]$.
\end{abstract}

Conclusion: Based on our findings, increased EAT may be suggested as an independent risk factor for AAD due to local or systemic effects in hypertensive patients.

Keywords: Epicardial adipose tissue, Ascending aortic dilatation, Hypertension

\section{Background}

Ascending aortic aneurysms and dissections are one of the major causes of mortality [1]. Despite important recent development in understanding of its pathogenesis, the role of haemodynamics and other reasons are partially known yet. The pathogenesis of ascending aortic dilatation (AAD) includes several factors with systemic and local effects. The aetiology is multifactorial, including environmental and genetic factors that play important roles in progression of aortic disease [2]. Given that

* Correspondence: onur_argan@yahoo.com

Department of Cardiology, Balikesir University Medical Faculty, 10440 Balıkesir, Turkey

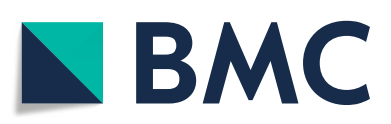

the pathogenesis of AAD maintains unclear, the main reason seems to be related to the deficiencies or defects in structural proteins, such as collagen and elastin in the aortic wall [3]. Changes of the extracellular matrix are suggested as a key factor in the pathogenesis of AAD [2-4]. Cystic medial degeneration responsible for weakened aortic wall is related to the degeneration of smooth muscle cell and elastic fibre apoptosis [5]. Also, the inflammatory process associated with atherosclerosis causes aortic dilatation [6].

Hypertension is one of the considerable risk factors for $\mathrm{AAD}$. AAD is often observed in hypertensive patients compared with normotensive individuals and is correlated

(c) The Author(s). 2020 Open Access This article is licensed under a Creative Commons Attribution 4.0 International License, which permits use, sharing, adaptation, distribution and reproduction in any medium or format, as long as you give appropriate credit to the original author(s) and the source, provide a link to the Creative Commons licence, and indicate if changes were made. The images or other third party material in this article are included in the article's Creative Commons licence, unless indicated otherwise in a credit line to the material. If material is not included in the article's Creative Commons licence and your intended use is not permitted by statutory regulation or exceeds the permitted use, you will need to obtain permission directly from the copyright holder. To view a copy of this licence, visit http://creativecommons.org/licenses/by/4.0/ The Creative Commons Public Domain Dedication waiver (http://creativecommons.org/publicdomain/zero/1.0/) applies to the data made available in this article, unless otherwise stated in a credit line to the data. 
with cardiac and noncardiac organ injury in hypertensive patients [2-4]. Hypertension is one of the most common diseases and a worldwide health problem. It is related to stroke, renal disease, cardiac disease, aortic disease, mortality and morbidity. It generally progresses silently until it causes end organ damage. However, it is a treatable and preventable disease.

In recent years, there is a growing interest towards the effects of epicardial adipose tissue (EAT) on hypertension and cardiovascular risk factors. EAT is a visceral adipose tissue found between the pericardium and the myocardium [7]. It is generally placed in the atrioventricular and interventricular groove throughout the coronary arteries. There is no any fascia between the myocardium and EAT; therefore, they have same microcirculation. EAT secretes antiinflammatory and antiatherogenic mediators and supplies energy to the myocardium [8-10]. However, under pathological conditions, EAT appears to play a critical role in atherosclerosis, hypertension and progression of metabolic diseases as it acts as a proinflammatory and prothrombotic organ [11]. Tumour necrosis factor alpha, interleukin-6 and monocyte chemoattractant protein-1, secreted from the EAT [12], immediately affect atherosclerosis $[13,14]$. As a result, increased EAT is related to atherosclerosis [15]. EAT may play a provocative role for $\mathrm{AAD}$ with paracrine and systemic endocrine effects on vessels [16].

Paracardial adipose tissue (PAT) is an ectopic fat depot surrounding the heart $[17,18]$. It is placed anterior to the EAT and outside the parietal layer of the pericardium [19]. The pericardium restricts the communication between the PAT and EAT. Studies about the different roles between EAT and PAT are limited. A few studies showed that PAT was more closely related with abdominal visceral adipose tissue and metabolic risk than EAT. It is also recommended that PAT might be a marker for increased metabolic risk and visceral adipose tissue on thoracic imaging [17-21].

The focus of the studies has been commonly on EAT, neglecting the potentially additive effects by the PAT on cardiovascular diseases. The aim of this study was to investigate the associations of EAT, and PAT with AAD in hypertensive patients.

\section{Methods}

The present study included 934 hypertensive patients who underwent complete transthoracic echocardiographic examination involving measurements of aortic dimensions, EAT and PAT. When diagnosing AAD, we used the body surface area (BSA)-adjusted classifications. For this purpose, we used Roman's classification (aortic size index, ASI) [22]. ASI was calculated by the following formula: ASI $=$ AA diameter $(\mathrm{mm}) / \mathrm{BSA}\left(\mathrm{m}^{2}\right)$ [23]. AAD was defined as a ASI $\geq 21 \mathrm{~mm} / \mathrm{m}^{2}$ according to the Roman's classification [23]. A total of 102 hypertensive patients with AAD were compared with 832 hypertensive patients with normal aortic diameter. Exclusion criteria were bicuspid and rheumatic aortic valve disease, Marfan syndrome, Ehlers-Danlos syndrome, Familial Thoracic Aortic Aneurysm Syndrome, Turner Syndrome and other connective tissue disorders, infectious conditions, restrictive and hypertrophic cardiomyopathy, renal failure requiring dialysis, malignancy and pregnancy. Hypertension was defined as the documentation of a blood pressure of more than $140 / 90 \mathrm{mmHg}$ or the use of antihypertensive drugs.

The study was approved by the Institutional Ethics Committee and conducted in accordance with the principles set out in the Declaration of Helsinki.

The demographic data included gender, age, body mass index (BMI), a history of coronary artery disease (CAD) and diabetes mellitus (DM). BMI was calculated by the following formula: $\mathrm{BMI}=$ weight $(\mathrm{kg}) /$ height $^{2}(\mathrm{~m})$. BSA was calculated using formule; BSA $\left(\mathrm{m}^{2}\right)=([$ Height $(\mathrm{cm}) \mathrm{x}$ Weight $(\mathrm{kg})] / 3600)^{1 / 2}$. The echocardiographic data involved EAT, PAT, ejection fraction (EF), left ventricle end diastolic diameter (LVEDD), left atrium (LA) diameter, right ventricle diameter and mitral, aortic and tricuspid valve diseases.

For biochemical data, we collected haemoglobin $(\mathrm{Hb})$, haematocrit (Htc), white blood cell count, platelet, creatinine, urea, $\mathrm{HbA1c}$, aspartate transaminase (AST), alanine transaminase (ALT), total cholesterol, HDL cholesterol, LDL cholesterol and triglyceride levels. The estimated glomerular filtration rate (eGFR) was calculated using the Modification of Diet in Renal Disease formula.

Transthoracic echocardiography was carried out using a Vivid S5 GE Healthcare system. Each patient underwent two-dimensional transthoracic echocardiography according to the recommendations of the European Association of Echocardiography [24]. Parasternal long axis view was used to view the proximal AA. The ascending aortic diameters were calculated between the inner edges of the aortic lumen perpendicular to the long axis $2 \mathrm{~cm}$ above the sinotubular junction at the end of the diastole in views showing the largest aortic diameter [16]. The parasternal long axis view was performed to measure maximal EAT thickness. EAT was defined as echo-free space between the outer wall of the myocardium and the visceral layer of the pericardium [14]. PAT was defined as the hypoechoic space in front of EAT and on the external pericardium [14-25]. The values were measured in three cardiac cycles and were averaged.

\section{Statistical analysis}

The SPSS 13.0 (SPSS Inc., an IBM Company, Chicago, USA) was used for statistical analyses. Data were tested for distribution using the Kolmogorov-Smirnov test. 
Table 1 Baseline characteristics of patients with and without aortic dilatation

\begin{tabular}{|c|c|c|c|}
\hline Characteristic & $\begin{array}{l}\text { Aortic Dilatation } \\
(n=102)\end{array}$ & $\begin{array}{l}\text { Normal Aorta } \\
(n=832)\end{array}$ & $P$-value \\
\hline Age (years) & $72.3 \pm 11.6$ & $61.7 \pm 12.7$ & $<0.001$ \\
\hline Female $n(\%)$ & $67(66)$ & $446(54)$ & 0.021 \\
\hline Body mass index $\left(\mathrm{kg} / \mathrm{m}^{2}\right)$ & $26.8 \pm 4.5$ & $30.7 \pm 4.9$ & $<0.001$ \\
\hline $\mathrm{BSA}\left(\mathrm{m}^{2}\right)$ & $1.70 \pm 0.19$ & $1.90 \pm 0.19$ & $<0.001$ \\
\hline Height (m) & $156 \pm 8$ & $164 \pm 9$ & $<0.001$ \\
\hline Weight (kg) & $66 \pm 13$ & $83 \pm 14$ & $<0.001$ \\
\hline Coronary Artery disease $n(\%)$ & $29(29)$ & $195(23)$ & 0.265 \\
\hline Diabetes mellitus $n(\%)$ & $18(18)$ & $245(29)$ & 0.012 \\
\hline Dyslipidemia $n(\%)$ & $33(32)$ & $272(33)$ & 0.945 \\
\hline \multicolumn{4}{|l|}{ Echocardiographic parameters } \\
\hline Ejection fraction (\%) & $57.6 \pm 7.4$ & $59.4 \pm 5.7$ & 0.005 \\
\hline Epicardial adipose tissue $(\mathrm{cm})$ & $0.48 \pm 0.15$ & $0.44 \pm 0.11$ & $<0.001$ \\
\hline Paracardial adipose tissue $(\mathrm{cm})$ & $0.49 \pm 0.18$ & $0.49 \pm 0.17$ & 0.738 \\
\hline Ascending aortic diameter (mm) & $38.5 \pm 4.2$ & $34.0 \pm 3.6$ & $<0.001$ \\
\hline LVEDD (mm) & $48.6 \pm 4.6$ & $47.8 \pm 4.0$ & 0.092 \\
\hline Left atrium diameter (mm) & $38.2 \pm 5.9$ & $36.4 \pm 5.7$ & 0.004 \\
\hline Right ventricular diameter (mm) & $23.1 \pm 2.5$ & $23.2 \pm 2.9$ & 0.628 \\
\hline Left ventricular hypertrophy $n(\%)$ & $44(44)$ & $280(34)$ & 0.042 \\
\hline$E$ & $80 \pm 25$ & $78 \pm 24$ & 0.461 \\
\hline A & $89 \pm 18$ & $83 \pm 18$ & 0.003 \\
\hline E/A & $0.9 \pm 0.3$ & $1.0 \pm 0.3$ & 0.057 \\
\hline$e^{\prime}$ & $6.9 \pm 1.7$ & $7.3 \pm 1.9$ & 0.046 \\
\hline$E / e^{\prime}$ & $11.9 \pm 3.3$ & $11.3 \pm 4.4$ & 0.158 \\
\hline Mitral regurgitation & & & $<0.001$ \\
\hline Grade-1 $n$ (\%) & $25(25)$ & $155(19)$ & \\
\hline Grade-2 n (\%) & $14(14)$ & $50(6)$ & \\
\hline Grade-3 n (\%) & $4(4)$ & $9(1)$ & \\
\hline Aortic regurgitation & & & $<0.001$ \\
\hline Grade-1 n (\%) & $30(29)$ & $129(16)$ & \\
\hline Grade-2 n (\%) & $20(20)$ & $47(6)$ & \\
\hline Grade-3 n (\%) & $4(4)$ & $3(0)$ & \\
\hline Tricuspid regurgitation & & & 0.007 \\
\hline Grade-1 n (\%) & $42(41)$ & $342(41)$ & \\
\hline Grade-2 n (\%) & $15(15)$ & $68(8)$ & \\
\hline Grade-3 n (\%) & $10(10)$ & $38(5)$ & \\
\hline Aortic stenosis & & & $<0.001$ \\
\hline Grade-1 n (\%) & $9(9)$ & $12(1)$ & \\
\hline Grade-2 n (\%) & $1(1)$ & $5(1)$ & \\
\hline Grade-3 n (\%) & $1(1)$ & $0(0)$ & \\
\hline \multicolumn{4}{|l|}{ Medications } \\
\hline Calcium canal bloker $n(\%)$ & $46(45)$ & $401(48)$ & 0.554 \\
\hline ACE -I/ARB $n(\%)$ & $65(64)$ & $553(67)$ & 0.581 \\
\hline Beta-bloker n (\%) & $48(47)$ & $275(33)$ & 0.005 \\
\hline
\end{tabular}


Table 1 Baseline characteristics of patients with and without aortic dilatation (Continued)

\begin{tabular}{|c|c|c|c|}
\hline Characteristic & $\begin{array}{l}\text { Aortic Dilatation } \\
(n=102)\end{array}$ & $\begin{array}{l}\text { Normal Aorta } \\
(n=832)\end{array}$ & $P$-value \\
\hline Doxazosine $n(\%)$ & $2(2)$ & $31(4)$ & 0.362 \\
\hline Thiazide diuretic $n(\%)$ & $46(46)$ & $415(50)$ & 0.450 \\
\hline Statin $n(\%)$ & $24(24)$ & $151(18)$ & 0.189 \\
\hline Acetylsalicylic acid $n$ (\%) & $23(23)$ & $192(23)$ & 0.905 \\
\hline \multicolumn{4}{|l|}{ Biochemical parameters } \\
\hline Hemoglobin (g/dl) & $12.7 \pm 2.0$ & $13.4 \pm 1.7$ & $<0.001$ \\
\hline WBC $\left(/ \mathrm{mm}^{3}\right)$ & $6.9 \pm 2.0$ & $7.3 \pm 2.1$ & 0.085 \\
\hline Platelet $\left(\times 10^{3} / \mu \mathrm{L}\right)$ & $232 \pm 79$ & $249 \pm 74$ & 0.032 \\
\hline eGFR (ml/min) & $68.9 \pm 22.0$ & $78.1 \pm 19.1$ & $<0.001$ \\
\hline Glucose (mg/dl) & $10.9 .6 \pm 24.7$ & $125.7 \pm 53.0$ & 0.003 \\
\hline $\mathrm{HbA1c}(\%)$ & $6.2 \pm 0.7$ & $6.5 \pm 1.3$ & 0.033 \\
\hline Total Cholesterol (mg/dl) & $201 \pm 27$ & $200 \pm 29$ & 0.876 \\
\hline LDL Cholesterol (mg/dl) & $123 \pm 32$ & $118 \pm 30$ & 0.108 \\
\hline HDL Cholesterol (mg/dl) & $48 \pm 11$ & $47 \pm 10$ & 0.324 \\
\hline Triglyceride (mg/dl) & $132(92-180)$ & 167 (109-209) & 0.004 \\
\hline AST (U/L) & $19(17-23)$ & $22(18-26)$ & 0.002 \\
\hline $\mathrm{ALT}(\mathrm{U} / \mathrm{L})$ & $14(12-19)$ & $18(14-25)$ & $<0.001$ \\
\hline
\end{tabular}

BSA body surface area, AST Aspartate transaminase, ALT Alanine transaminase, WBC White blood cell count, LVEDD Left ventricular end diastolic diameter, eGFR Estimated glomerular filtration rate. ACE Angiotensin-converting enzyme inhibitors, Angiotensin II receptor blockers, $B M I$ body mass index

Categorical variables were introduced as percentages. Continuous variables were introduced as mean $\pm \mathrm{SD}$, and abnormally distributed variables are introduced as median (25-75 percentages). Normally distributed continuous variables were analysed with the 2-tailed Student's $t$ test, and not normally distributed variables were analysed with the Mann-Whitney $U$ test. Categorical data were analysed using the Fisher's exact test or chi square. Pearson and Spearman tests were used for correlation analysis. Since the study was nonrandomized, a logistic regression model with propensity scores was created in order to balance patient characteristics and perform propensity-matched analysis of the patients with and without AAD. Clinical determinants of the hypertensive patients with AAD were established using univariate and multivariable logistic regression analyses. Logistic regression analyses were performed for the multivariate analysis of independent variables, which were included if they were statistically significant in the univariate analyses. Receiver-operating characteristic (ROC) curve graphics were used to determine the cutoff value of EAT. A $p$ value $<0.05$ was accepted as statistically significant.

\section{Results}

A total of 934 hypertensive patients were divided into the following two groups: patients with ascending aortic dilatation (AAD) (102 patients) and patients with normal ascending aorta (AA) (832 patients). Baseline characteristics and echocardiographic and biochemical parameters are summarised in Table 1.

Patients with AAD were older than the patients with normal AA $(72.3 \pm 11.6$ vs. $61.7 \pm 12.7$ years, $p<0.001)$, had more female gender $(66 \%$ vs. $54 \%, p=0.021)$ compared with patients with normal ascending aorta (AA). BMI and BSA were lower in patients with AAD than patients with normal AA (Table 1). EAT thickness $(0.48 \pm$ $0.15, p<0.001)$ was significantly higher in the patients with AAD compared with the patients with normal AA. There was no difference between groups regarding PAT thickness $(0.49 \pm 0.18$ vs $0.49 \pm 0.17, p=0.738)$. $\beta$ Blocker usage is higher in patients with AAD than patients with normal AA.

In biochemical analyses, eGFR was lower in patients with AAD than patients with normal AA $(68.9 \pm 22.0$ vs $78.1 \pm 19.1, p<0.001$ ).

After propensity score matching analysis (77 vs. 77), EAT and age were significantly higher in patients with $A A D$ than those without $\mathrm{AAD}(0.49 \pm 0.16$ vs $0.42 \pm 0.10, P=0.002$; $69.8 \pm 11.4$ vs $64.4 \pm 11.3, p<0.001$, respectively). Characteristics of the population after matching are presented in Table 2. In the matched population, EAT was associated with $\mathrm{AAD}$ in multivariate logistic regression analysis [OR: 1.461, \%95CI (1.082-1.974), $p=0.013$ ] (Table 3).

ROC curve analysis was performed to predict $A A D$ in the matched population (Fig. 1). EAT $>0.45 \mathrm{~cm}$ had $51.9 \%$ sensitivity and $62.3 \%$ specificity [AUC $=0.617, P=$ 0.012, 95\% CI (0.529-0.707)]. 
Table 2 Baseline characteristics of patients with and without aortic dilatation after matching.

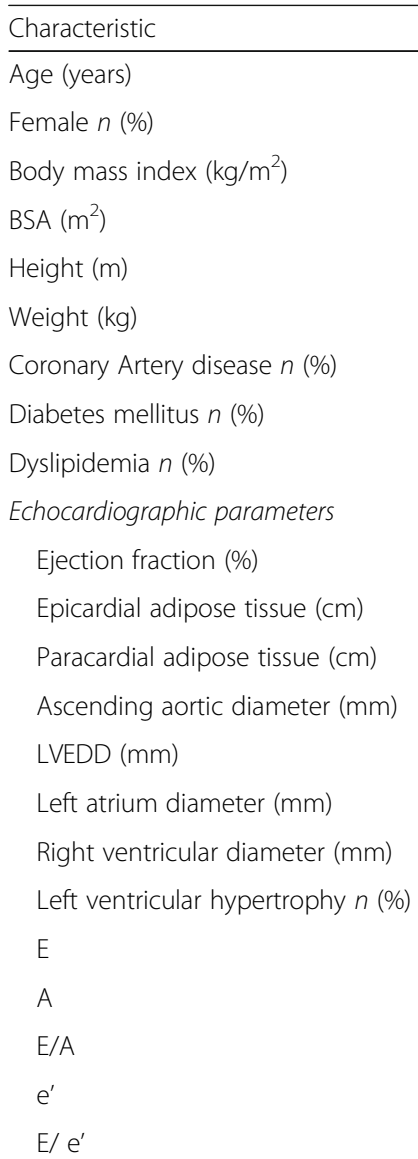

Mitral regurgitation

\section{Grade-1 $n$ (\%)}

Grade-2 $n$ (\%)

Grade-3 $n$ (\%)

Aortic regurgitation

Grade-1 $n(\%)$

Grade-2 $n(\%)$

Grade-3 $n$ (\%)

Tricuspid regurgitation

Grade-1 $n$ (\%)

Grade-2 n (\%)

Grade-3 n (\%)

Aortic stenosis

Grade-1 n (\%)

Grade-2 $n$ (\%)

Grade-3 n (\%)

Medications

Calcium canal bloker $n$ (\%)

ACE -I/ARB $n(\%)$

Beta-bloker $n$ (\%)

Doxazosine $n(\%)$

Aortic Dilatatir
$69.8 \pm 11.4$
$50(65)$
$27.8 \pm 4.5$
$1.74 \pm 0.16$
$158 \pm 8$
$70 \pm 11$
$25(33)$
$15(15)$
$28(36)$
$58.0 \pm 7.3$
$0.49 \pm 0.16$
$0.49 \pm 0.18$
$39.0 \pm 3.8$
$48.8 \pm 4.5$
$38.3 \pm 6.1$
$23.1 \pm 2.5$
$32(42)$
$80 \pm 25$
$87 \pm 18$
$0.9 \pm 0.3$
$7.1 \pm 1.6$
$11.7 \pm 3.3$

18 (23)

11 (14)

$2(0)$

21 (27)

11 (14)

2 (3)

$32(42)$

10 (13)

$6(8)$

$4(5)$

$0(0)$

$0(0)$

35 (46)

50 (65)

$31(40)$

2 (3)

\begin{tabular}{ll} 
Normal Aorta $(n=77)$ & $P$-value \\
\hline $64.4 \pm 11.3$ & $<0.001$ \\
$48(62)$ & 0.014 \\
$29.6 \pm 5.1$ & 0.018 \\
$1.87 \pm 0.25$ & $<0.001$ \\
$162 \pm 11$ & 0.021 \\
$78 \pm 18$ & 0.001 \\
$13(17)$ & 0.025 \\
$15(15)$ & 1.000 \\
$23(30)$ & 0.392
\end{tabular}

$58.5 \pm 6.2$

0.679

$0.42 \pm 0.10$

0.002

$0.49 \pm 0.17$

0.941

$29.3 \pm 3.1$

$<0.001$

$46.8 \pm 4.3$

0.005

$35.0 \pm 6.9$

0.002

$22.7 \pm 3.4$

0.416

23 (30)

0.130

$78 \pm 21$

0.610

$86 \pm 16$

0.639

$0.9 \pm 0.2$

0.478

$7.5 \pm 2.0$

0.234

$11.1 \pm 3.6$

0.344

0.189

19 (25)

5 (7)

$0(0)$

0.710

17 (22)

15 (20)

1 (1)

0.595

35 (46)

5 (7)

7 (9)

0.565

3 (4)

(1)

0 (0)

35 (46)

1.000

47 (61)

0.617

24 (31)

0.239

1 (1) 
Table 2 Baseline characteristics of patients with and without aortic dilatation after matching. (Continued)

\begin{tabular}{|c|c|c|c|}
\hline Characteristic & Aortic Dilatation $(n=77)$ & Normal Aorta $(n=77)$ & $P$-value \\
\hline Thiazide diuretic $n(\%)$ & $37(48)$ & $34(44)$ & 0.628 \\
\hline Statin $n(\%)$ & $22(29)$ & $10(13)$ & 0.017 \\
\hline Acetylsalicylic acid $n$ (\%) & $21(27)$ & $11(14)$ & 0.047 \\
\hline \multicolumn{4}{|l|}{ Biochemical parameters } \\
\hline Hemoglobin (g/dl) & $12.9 \pm 1.8$ & $13.0 \pm 1.8$ & 0.671 \\
\hline WBC $\left(/ \mathrm{mm}^{3}\right)$ & $7.2 \pm 2.0$ & $7.1 \pm 2.1$ & 0.639 \\
\hline Platelet $\left(\times 10^{3} / \mu \mathrm{L}\right)$ & $243 \pm 74$ & $250 \pm 83$ & 0.570 \\
\hline eGFR (ml/min) & $72.2 \pm 21.2$ & $77.4 \pm 16.5$ & 0.093 \\
\hline Glucose (mg/dl) & $112.3 \pm 26.8$ & $108.1 \pm 25.1$ & 0.320 \\
\hline $\mathrm{HbA1c}(\%)$ & $6.3 \pm 0.7$ & $6.2 \pm 0.9$ & 0.474 \\
\hline Total Cholesterol (mg/dl) & $201 \pm 31$ & $201 \pm 25$ & 0.965 \\
\hline LDL Cholesterol (mg/dl) & $120 \pm 33$ & $120 \pm 32$ & 0.836 \\
\hline HDL Cholesterol (mg/dl) & $48 \pm 12$ & $47 \pm 10$ & 0.774 \\
\hline Triglyceride (mg/dl) & $134(91-180)$ & 140 (107-181) & 0.994 \\
\hline AST (U/L) & $19(17-22)$ & $22(19-26)$ & 0.231 \\
\hline ALT (U/L) & $15(12-18)$ & $17(13-24)$ & 0.459 \\
\hline
\end{tabular}

BSA body surface area, AST Aspartate transaminase, ALT Alanine transaminase, WBC White blood cell count, LVEDD Left ventricular end diastolic diameter, eGFR Estimated glomerular filtration rate. ACE Angiotensin-converting enzyme inhibitors, Angiotensin II receptor blockers, $B M I$ body mass index

\section{Discussion}

In this study, we found that EAT are independent predictor for AAD in hypertensive patients.

The normal diameter of the AA depends on the patient's age, sex and body size [26]. Similarly to our study, Bon et al. showed that higher age was associated with larger descending aortic diameters. The causes of aortic aneurysms differ according to the location of the aorta. In younger patients, thoracic aortic aneurysms with genetic reasons generally include the AA and aortic root. These reasons include connective tissue disorders, such as Ehlers-Danlos Syndrome, Marfan Syndrome, Loeys-Dietz Syndrome, Familial Thoracic Aortic Aneurysm Syndrome, Turner Syndrome and bicuspid aortic valve. Also, cystic medial degeneration can be seen in thoracic aortic aneurysms that are not due to a connective tissue disorder but have a genetic connection. Other reasons of thoracic aortic aneurysms are aortitis (syphilis is the most common cause) or inflammation of the aorta. A total of $39 \%$ of the variance in descending aortic diameter and $21 \%$ of the variance in ascending aortic diameter were explained by sex, age, traditional cardiovascular risk factors and anthropometrics [27]. Consequently, only a small part of the causes of ascending aortic aneurysm could be explained by conventional risk factors. The influence of these cardiovascular risk factors seems of limited importance in elucidating the overall reasons for aortic dilatation.

EAT may help fill this gap. There are two possible mechanisms for the association between EAT and AAD. First, EAT has a paracrine and systemic endocrine role. It can secrete several active molecules, such as tumour necrosis factor, resistin, adiponectin and IL-6 [28, 29]. Second, EAT is one of the parts of the visceral adipose tissue, and, therefore, it is associated with CAD, cardiovascular

Table 3 Univariate and multivariate analysis of ascending aort dilatation

\begin{tabular}{llll}
\hline Variables & Univariate & P-value & $\begin{array}{c}\text { Multivariate } \\
\text { OR(95\% Cl) }\end{array}$ \\
\hline Age (years) & $1.030(1.006-1.056)$ & 0.016 & \\
Coronary artery disease & $1.548(1.155-2.074)$ & 0.027 & \\
Female & $1.119(0.580-2.158)$ & 0.738 & \\
Statin & $2.680(1.171-6.135)$ & 0.020 & \\
ASA & $2.250(0.999-5.067)$ & 0.050 & \\
eGFR (mL/min) & $0.985(0.969-1.003)$ & 0.014 & $1461(1.082-1.974)$ \\
EAT thickness $(\mathrm{mm})$ & $1.548(1.155-2.074)$ & 0.003 &
\end{tabular}

eGFR Estimated glomerular filtration rate, ASA acetylsalicylic asid, EAT Epicardial adipose tissue 


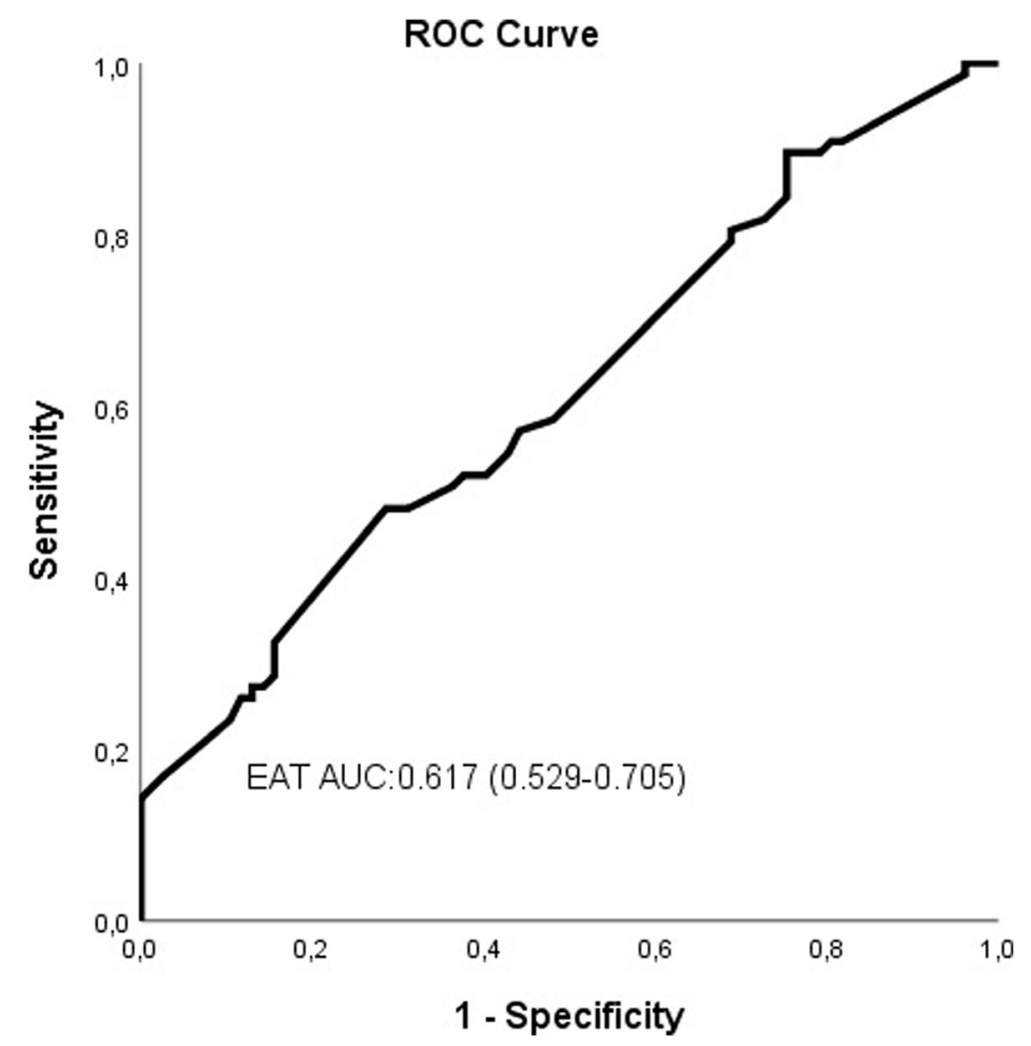

Fig. 1 Receiver operating characteristic (ROC) curves for EAT in predicting of AAD

risk factors, hypertension and metabolic syndrome [3032]. These specifications of EAT may be a possible causative role of AAD.

In the literature, PAT and EAT have been used interchangeably, because they were thought to be identical adipose depots. However, paracardial and epicardial adipose tissues are clearly different embriologically, physiologically, anatomically and clinically. Despite this, the literature frequently contradictorily discriminates between the two adipose tissues [33]. EAT is the fat depot placed between the myocardium and visceral pericardium, whereas PAT is the fat depot outside the pericardium and on the external surface of the parietal pericardium as defined by imaging studies and autopsies [14-34]. So, EAT is the adipose tissue depot immediately adjacent to the myocardium, whereas PAT is the outer adipose tissue of the heart.

EAT originates from the splanchnopleuric mesoderm, whereas PAT originates from the thoracic primitive mesenchyme. EAT is supplied by the coronary arteries, whereas PAT is supplied by the noncoronary system. Also, no any fascia separates the EAT and coronary arteries; therefore, EAT and myocardium share the same circulation. Because of this link, EFT is metabolically an active tissue and the source of cytokines and interacts directly through vasocrine and paracrine mechanisms to the myocardium, coronary and systemic circulation [34].
This is not true for PAT. PAT does not directly interact with the myocardium and may only contact indirectly through acts like ectopic visceral adipose tissue. As a result, pericardial and EATs are clinically different [35].

$\mathrm{CAD}$ is correlated with $\mathrm{AAD}$ in univariate regression analysis, but this correlation was not determined in multivariate regression analysis after matching. Atherosclerosis can lead to aortic dilatation, especially in aortic arch and descending aorta. Unlike dilatation of the descending aorta, the role of atherosclerosis in the aetiology of AAD is controversial, and AAD is not generally due to atherosclerosis. Most aetiology of the AADs are classified as idiopathic [36, 37].

Interestingly, the presence of DM was related to a smaller ascending and descending aortic diameter in the literature [38]. This phenomenon might be caused by high glucose levels associated with DM which inhibits intermediate-phase secretion of the matrix metalloproteinases. Similarly, protective effect of DM has already been shown in the abdominal aorta [39, 40]. However, this phenomenon may be more remarkable in abdominal aorta than AA. We did not find any relationship between DM and AAD.

It has been shown that there was a relationship between EAT density and arterial inflammation and cardiovascular risk prediction. This adipose tissue-arterial 
wall association may play a role in the formation of AAD [41].

The findings of this study may support the hypothesis that increased EAT, but not PAT, may have a critical role in AAD.

\section{Conclusion}

Only a little part of the aetiology of AAD was explained by age, sex, traditional cardiovascular risk factors and anthropometrics. EAT may have a key role in AAD. Based on our findings, increased EAT, and BMI were independent predictors for AAD in hypertensive patients. Increased EAT may be effective in progressing aortic dilatation due to local or systemic effects. However, this relationship was not observed in PAT. We believe that further studies are needed to explain the role of different types of adipose tissue in the pathogenesis of AAD. Adipose tissue-focused diagnosis and treatments can provide new insight to the patients with AAD.

\section{Study limitations}

This was primarily a cross-sectional study retrospective in nature. MRI and computed tomography are frequently used in the evaluation of adipose tissue. Although MRI is the modality of choice for water/fat separation, CT is considered to gold standard for volumetric adipose tissue analyses. However, we used echocardiography to measure EAT. Also, there are some limitations to the measurement of EAT and PAT by echocardiography. Echocardiographic imaging only allows for a rough estimation of the adipose tissue [42, 43]. The restricted acoustic window limits the imaging of total adipose tissue volume and determining regional differences in adipose tissue distribution. Nevertheless, there is a close correlation between MRI and echocardiography imaging of EAT $[44,45]$. In our study, predictive value of EAT for AAD was modest. The cutt-off values of epicardial fat for AAD prediction are not well defined in literature. Whether or not echocardiographic epicardial fat thickness may really have the diagnostic properties to serve as an indicator of AAD should be analyzed in large, randomized studies.

\section{Abbreviations \\ EAT: Epicardial adipose tissue; AAD: Ascending aortic dilatation; BMI: Body mass index; PAT: Paracardial adipose tissue; BSA: Body surface area; CAD: Coronary artery disease; DM: Diabetes mellitus; AA: Ascending aorta; EF: Ejection fraction; LVEDD: Left ventricle end diastolic diameter; LA: Left atrium; Hb: Haemoglobin; Htc: Haematocrit; AST: Aspartate transaminase; ALT: Alanine transaminase; eGFR: Estimated glomerular filtration rate}

\section{Acknowledgements}

Not applicable.

\section{Authors' contributions}

All of the authors participated in the conception of the study. The reviews were made by OA, EA, TY, OS. The study design and analysis were made by OA, EA. Data collection were made by OA. The field work was performed by
OA, TY, OS. The manuscript were written by OA. All of the authors participated in the review of the article with important contributions and accepted the final version. The author(s) read and approved the final manuscript.

\section{Funding}

Not applicable.

\section{Availability of data and materials}

The datasets used and analyzed during the current study are available from the corresponding author on reasonable request.

\section{Ethics approval and consent to participate}

The study was designed retrospectively. Kocaeli University Ethics Committee waivered the need for informed consent regarding the retrospective data and approved this study.

\section{Consent for publication \\ Not applicable.}

\section{Competing interests}

The authors declare that they have no competing interests.

Received: 21 November 2019 Accepted: 12 March 2020

Published online: 19 March 2020

\section{References}

1. Hiratzka LF, Bakris GL, Beckman JA, Bersin RM, Carr VF, Casey DE, et al. 2010 ACCF/AHA/AATS/ACR/ASA/SCA/SCAI/SIR/STS/SVM guidelines for the diagnosis and management of patients with thoracic aortic disease. J Am Coll Cardiol. 2010;55:e27-e129.

2. Ramanath VS, Oh JK, Sundt TM, Eagle KA. Acute aortic syndromes and thoracic aortic aneurysm. Mayo Clin Proc. 2009;84:465-81.

3. Baxter BT, Davis VA, Minion DJ, Wang YP, Lynch TG, McManus BM. Abdominal aortic aneurysms are associated with altered matrix proteins of the nonaneurysmal aortic segments. J Vasc Surg. 1994;19:797-803.

4. El-Hamamsy I, Yacoub MH. Cellular and molecular mechanisms of thoracic aortic aneurysms. Nature Rev Cardiol. 2009;6:771-86.

5. Albornoz G, Coady MA, Roberts M, Davies RR, Tranquilli M, Rizzo JA, et al. Familial thoracic aortic aneurysms and dissections - incidence, modes of inheritance, and phenotypic patterns. Ann Thorac Surg. 2006;82:1400-5.

6. Libby P, Ridker PM, Maseri A. Inflammation and atherosclerosis. Circulation. 2002;105:1135-43.

7. Acele A, Baykan AO, Yüksel Kalkan G, Çeliker E. Epicardial fat thickness is associated with aortic intima-media thickness in patients without clinical manifestation of atherosclerotic cardiovascular disease. Echocardiography. 2017;34(8):1146-51. https://doi.org/10.1111/echo.13600.

8. lacobellis G, Bianco AC. Epicardial adipose tissue: emerging physiological, pathophysiological and clinical features. Trends Endocrinol Metab. 2011; 22(11):450-7. https://doi.org/10.1016/j.tem.2011.07.003 Epub 2011 Aug 16. Review.

9. Ferdinand KC, Nasser SA. Management of essential hypertension. Cardiol Clin. 2017;35:231-46.

10. Acet $H$, Ertas F, Akil MA, et al. New inflammatory predictors for non-valvular atrial fibrillation: echocardiographic epicardial fat thickness and neutrophil to lymphocyte ratio. Int J Cardiovasc Imaging. 2014;30:81-9.

11. Salazar J, Luzardo E, Mejías JC, Rojas J, Ferreira A, Rivas-Ríos JR, Bermúdez V. Epicardial fat: physiological, pathological, and therapeutic implications. Cardiol Res Pract. 2016;2016:1291537. https://doi.org/10.1155/2016/1291537 Epub 2016 Apr 26. Review.

12. Talman AH, Psaltis PJ, Cameron JD, Meredith IT, Seneviratne SK, Wong DT. Epicardial adipose tissue: far more than a fat depot. Cardiovasc Diagn Ther. 2014;4(6):416-29. https://doi.org/10.3978/j.issn.2223-3652.2014.11.05 Review.

13. Parsaei MS, Nabati M, Yazdani J, Bagheri B, Ghaemian A, Saffar N. Relationship between epicardial fat and coronary microvascular dysfunction. Kardiol Pol. 2014;72(5):417-24. https://doi.org/10.5603/KP.a2013.0347.

14. lacobellis $\mathrm{G}$, Willens HJ. Echocardiographic epicardial fat: a review of research and clinical applications. J Am Soc Echocardiogr. 2009;22:1311-9.

15. Bertaso AG, Bertol D, Duncan BB, Foppa M. Epicardial fat: definition, measurements and systematic review of main outcomes. Arq Bras Cardiol. 
2013;101(1):e18-28. https://doi.org/10.5935/abc.20130138 Review. English, Portuguese.

16. Cetin M, Kocaman SA, Durakoğlugil ME, Erdoğan T, Uğurlu Y, Doğan S, Çanga A. Independent determinants of ascending aortic dilatation in hypertensive patients: smoking, endothelial dysfunction, and increased epicardial adipose tissue. Blood Press Monit. 2012;17(6):223-30. https://doi. org/10.1097/MBP.0b013e328359c4a7.

17. Wheeler GL, Shi R, Beck SR, Langefeld CD, Lenchik L, Wagenknecht LE, Freedman BI, Rich SS, Bowden DW, Chen MY, Carr JJ. Pericardial and visceral adipose tissues measured volumetrically with computed tomography are highly associated in type 2 diabetic families. Investig Radiol. 2005;40(2):97101.

18. Fitzgibbons TP, Czech MP. Epicardial and perivascular adipose tissues and their influence on cardiovascular disease: basic mechanisms and clinical associations. J Am Heart Assoc. 2014;3(2):e000582. https://doi.org/10.1161/ JAHA.113.000582 Review.

19. El Khoudary SR, Shields KJ, Janssen I, Budoff MJ, Everson-Rose SA, Powell LH, Matthews KA. Postmenopausal Women With Greater Paracardial Fat Have More Coronary Artery Calcification Than Premenopausal Women: The Study of Women's Health Across the Nation (SWAN) Cardiovascular Fat Ancillary Study. J Am Heart Assoc. 2017;6(2). https://doi.org/10.1161/JAHA.116.004545.

20. Thanassoulis G, Massaro JM, Hoffmann U, Mahabadi AA, Vasan RS, O'Donnell CJ, et al. Prevalence, distribution, and risk factor correlates of high pericardial and intrathoracic fat depots in the Framingham heart study. Circ Cardiovasc Imaging. 2010;3:559-66.

21. Chen O, Sharma A, Ahmad I, Bourji N, Nestoiter K, Hua P, et al. Correlation between pericardial, mediastinal, and intrathoracic fat volumes with the presence and severity of coronary artery disease, metabolic syndrome, and cardiac risk factors. Eur Heart J Cardiovasc Imaging. 2015;16:37-46.

22. Roman MJ, Devereux RB, Kramer-Fox R, O'Loughlin J. Two-dimensional echocardiographic aortic root dimensions in normal children and adults. Am J Cardiol. 1989;64(8):507-12.

23. Davies RR, Gallo A. CoadyMAet al.; novel measurement of relative aortic size predicts rupture of thoracic aortic aneurysms. Ann Thorac Surg. 2006;81(1): 169-77.

24. Sicari R, Galderisi M, Voigt JU, Habib G, et al. The use of pocket-size imaging devices: a position statement of the European Association of Echocardiography. Eur J Echocardiogr. 2011;12:85-7.

25. Davidovich D, Gastaldelli A, Sicari R. Imaging cardiac fat. Eur Heart J Cardiovasc Imaging. 2013;14:625-30.

26. Salameh MJ, Black JH 3rd, Ratchford EV. Thoracic aortic aneurysm. Vasc Med. 2018;23(6):573-8. https://doi.org/10.1177/1358863X18807760 Epub 2018 Oct 29.

27. Farasat $\mathrm{SM}$, Morrell $\mathrm{CH}$, Scuteri $\mathrm{A}$, et al. Do hypertensive individuals have enlarged aortic root diameters? Insights from studying the various subtypes of hypertension. Am J Hypertens. 2008;21:558-63.

28. Sacks HS, Fain JN. Human epicardial fat: what is new and what is missing? Clin Exp Pharmacol Physiol. 2011;38(12):879-87. https://doi.org/10.1111/j. 1440-1681.2011.05601.x PMID: 21895738

29. Toczylowski K, Gruca M, Baranowski M. Epicardial adipose tissue and its role in cardiac physiology and disease. Postepy Hig Med Dosw (Online). 2013;67: 584-93. https://doi.org/10.5604/17322693.1053908.

30. Eroglu S, Sade LE, Yildirir A, Bal U, Ozbicer S, Ozqul AS, et al. Epicardial adipose tissue thickness by echocardiography is a marker for the presence and severity of coronary artery disease. Nutr Metab Cardiovasc Dis. 2009: 19(3):211-7. https://doi.org/10.1016/j.numecd.2008.05.002 PMID: 18718744.

31. Bachar GN, Dicker D, Kornowski R, Atar E. Epicardial adipose tissue as a predictor of coronary artery disease in asymptomatic subjects. Am J Cardiol. 2012;110(4):534-8. https://doi.org/10.1016/j.amjcard.2012.04.024 PMID: 225 79086.

32. Bruun JM, Lihn AS, Verdich C, Pedersen SB, Toubro S, Astrup A, et al. Regulation of adiponectin by adipose tissue-derived cytokines: in vivo and in vitro investigations in humans. Am J Physiol Endocrinol Metab. 2003;285: E527-33.

33. lacobellis G. Epicardial and pericardial fat: close, but very different. Obesity 2009;17:625

34. lacobellis G, Corradi D, Sharma AM. Epicardial adipose tissue: anatomic, biomolecular and clinical relationships with the heart. Nat Clin Pract Cardiovasc Med. 2005;2:536-43.

35. lacobellis G, Malavazos AE. Pericardial adipose tissue, atherosclerosis, and cardiovascular disease risk factors: the Jackson Heart Study: comment on Liu et Al. Diabetes Care. 2010;33(9):e127; author reply e128. https://doi.org/10. 2337/dc10-0904

36. Cuspidi C, Meani S, Fusi V, Valerio C, Sala C, Zanchetti A. Prevalence and correlates of aortic root dilatation in patients with essential hypertension: relationship with cardiac and extracardiac target organ damage. J Hypertens. 2006;24:573-80.

37. Cem O, Yilmaz S, Korkmaz A, Fahrettin T, Sahin I, Demir V. Evaluation of the neutrophil-lymphocyte ratio in newly diagnosed nondiabetic hypertensive patients with ascending aortic dilatation. Blood Press Monit. 2016;21(4):23843. https://doi.org/10.1097/MBP.0000000000000187.

38. Bons LR, Rueda-Ochoa OL, El Ghoul K, Rohde S, Budde RP, Leening MJ, Vernooij MW, Franco OH, van der Lugt A, Roos-Hesselink JW, Kavousi M, Bos D. Sex-specific distributions and determinants of thoracic aortic diameters in the elderly. Heart. 2019;24. pii: heartjnl-2019-315320. https://doi.org/10.1136/ heartinl-2019-315320.

39. Golledge J, Karan M, Moran CS, et al. Reduced expansion rate of abdominal aortic aneurysms in patients with diabetes may be related to aberrant monocyte-matrix interactions. Eur Heart J. 2008;29:665-72.

40. Lederle FA. The strange relationship between diabetes and abdominal aortic aneurysm. Eur J Vasc Endovasc Surg. 2012;43:254-6.

41. Antonopoulos AS, Sanna F, Sabharwal N, Thomas S, Oikonomou EK, Herdman $\mathrm{L}$, et al. Detecting human coronary inflammation by imaging perivascular fat. Sci Transl Med. 2017;9(398). https://doi.org/10.1126/ scitransImed.aal2658. PubMed PMID: 28701474.

42. Sicari R, Sironi AM, Petz R, et al. Pericardial rather than epicardial fat is a cardiometabolic risk marker: an MRI vs echo study. J Am Soc Echocardiogr. 2011;24:1156-62.

43. Eroglu S. How do we measure epicardial adipose tissue thickness by transthoracic echocardiography? Anatol J Cardiol. 2015;15:416-9.

44. lacobellis G, Assael F, Ribaudo MC, et al. Epicardial fat from echocardiography: a new method for visceral adipose tissue prediction. Obes Res. 2003;11:304-10.

45. Christensen RH, Hansen CS, von Scholten BJ, Jensen MT, Pedersen BK Schnohr P, Vilsbøll T, Rossing P, Jørgensen PG. Epicardial and pericardial adipose tissues are associated with reduced diastolic and systolic function in type 2 diabetes. Diabetes Obes Metab. 2019;21(8):2006-11. https://doi. org/10.1111/dom.13758.

\section{Publisher's Note}

Springer Nature remains neutral with regard to jurisdictional claims in published maps and institutional affiliations.

Ready to submit your research? Choose BMC and benefit from:

- fast, convenient online submission

- thorough peer review by experienced researchers in your field

- rapid publication on acceptance

- support for research data, including large and complex data types

- gold Open Access which fosters wider collaboration and increased citations

- maximum visibility for your research: over $100 \mathrm{M}$ website views per year

At $\mathrm{BMC}$, research is always in progress.

Learn more biomedcentral.com/submission 